Article

\title{
Backtracking to Parent Maceral from Produced Bitumen with Raman Spectroscopy
}

\author{
Seyedalireza Khatibi ${ }^{1}{ }^{\circledR}$, Arash Abarghani ${ }^{1}\left(\mathbb{D}\right.$, Kouqi Liu $^{2}$, Alexandra Guedes $\left.{ }^{3} \mathbb{(}\right)$, \\ Bruno Valentim ${ }^{3}$ (D) and Mehdi Ostadhassan $4, *$ (D) \\ 1 Department of Petroleum Engineering, University of North Dakota, Grand Forks, ND 58202, USA; \\ seyedalireza.khatibi@und.edu (S.K.); arash.abarghani@und.edu (A.A.) \\ 2 Department of Earth and Atmospheric Sciences, Central Michigan University, \\ Mount Pleasant, MI 48859, USA; liu3k@cmich.edu \\ 3 Instituto de Ciências da Terra-Pólo Porto, Departamento de Geociências, Ambiente e Ordenamento do \\ Território, Faculdade de Ciências, Universidade do Porto, rua do Campo Alegre s/n, \\ 4169-007 Porto, Portugal; aguedes@fc.up.pt (A.G.); bvvalent@fc.up.pt (B.V.) \\ 4 Key Laboratory of Continental Shale Hydrocarbon Accumulation and Efficient Development, Ministry of \\ Education, Northeast Petroleum University, Daqing 163318, China \\ * Correspondence: mehdi.ostadhassan@nepu.edu.cn
}

Received: 15 June 2020; Accepted: 28 July 2020; Published: 30 July 2020

check for updates

\begin{abstract}
In order to assess a source rock for economical exploitation purposes, many parameters should be considered; regarding the geochemical aspects, the most important ones are the amount of organic matter (OM) and its quality. Quality refers to the thermal maturity level and the type of OM from which it was formed. The origin of the OM affects the ability of the deposited OM between sediments to generate oil, gas, or both with particular potential after going through thermal maturation. Vitrinite reflectance and programmed pyrolysis (for instance, Rock-Eval) are common methods for evaluating the thermal maturity of the OM and its potential to generate petroleum, but they do not provide us with answers to what extent solid bitumen is oil-prone or gas-prone, as they are bulk geochemical methods. In the present study, Raman spectroscopy (RS), as a powerful tool for studying carbonaceous materials and organic matter, was conducted on shale and coal samples and their individual macerals to show the potential of this technique in kerogen typing and to reveal the parent maceral of the examined bitumen. The proposed methodology, by exhibiting the chemical structure of different organic matters as a major secondary product in unconventional reservoirs, can also detect the behavior of solid bitumen and its hydrocarbon production potential for more accurate petroleum system evaluation.
\end{abstract}

Keywords: Raman spectroscopy; maturity level; kerogen type; solid bitumen; maceral

\section{Introduction}

Kerogen is a macromolecule (geopolymer) that forms the insoluble portion of the dispersed organic matter $(\mathrm{OM})$ in source rocks and generates oil and natural gas through thermal maturation [1,2]. The capability of kerogen to generate oil or gas is dependent upon the maceral composition $[3,4]$ and its burial conditions (pressure and temperature); however, the effects of local parameters (e.g., local heat transfer) should not be ignored either [5,6]. Thermal maturity level is traditionally measured by reflectance methods such as vitrinite, solid bitumen, or zooclast (graptolites, chitinozoans, and scolecodonts) reflectance as the most reliable approaches. The biogenic origin of kerogen, also known as the parent maceral, is usually represented by the particulate organic matter and bitumen that is distinguished in rock samples as a phytogenic organic substance with distinct 
chemical/physical properties, through microscopic examination (transmitted and reflected white, and ultraviolet lights) [7-16]. Other methods includng infrared spectroscopy (through the various ratios of aromatic/aliphatic compounds $[17,18]$ ), programmed pyrolysis (e.g., Rock-Eval-derived $\mathrm{T}_{\max }$ ), liquid chromatography, gas chromatography, gas chromatography coupled with mass spectrometry, etc., could provide some information about its thermal maturity too $[19,20]$. Kerogen typing is not only useful to detect the origin and depositional environment (lacustrine, marine, and terrestrial) of recognized organic matter, but it also helps to develop models in regard to the OM petrophysical characteristics. For instance, as the thermal maturity of the $\mathrm{OM}$ advances, pore spaces are developed and evolves in it [21,22]. Ultimately, the combination of these studies will enable more precise petroleum system evaluation and petrophysical characterization, and finally reserve estimation in organic-rich shale plays.

Based on extensive organic petrography studies of source rock specimens, three major maceral groups of kerogens (Table 1) are identified considering their unique morphologies and grayness in reflected light $[23,24]$ :

- The liptinite group (Type I and II kerogen) includes primarily algal material or amorphous organic matter derived from algal or bacterial precursors,

- $\quad$ the vitrinite group (Type III kerogen) refers to organic matter that is derived from the woody tissue of post-Silurian vascular plants,

- and the inertinite group (Type IV kerogen) includes macerals that have experienced combustion, oxidation, or desiccation $[25,26]$.

In addition to these three major maceral groups, zooclasts and secondary products (solid bitumen) are also considered in the present study. Zooclasts are organic matter with reflecting surfaces that have a similar grayness to vitrinite or solid bitumen that can be distinguished based on their unique morphologies [27]. Secondary products are the consequence of OM transformation and are usually referred to as solid bitumen or other by-products. Secondary products like solid bitumen are an important thermal maturity indicator when vitrinite is scarce/absent [28-31]. Although solid bitumen is not considered as an independent kerogen type, it becomes the predominant organic matter at higher thermal maturities in samples within the late oil to dry gas window [26,32-34].

Table 1. Maceral groups classification of The Society for Organic Petrology/International Commission for Coal and Organic Petrology (TSOP/ICCP). (Modified from: $[25,26,28]$ ). Zooclast and Secondary products are not categorized in any kerogen type.

\begin{tabular}{cccc}
\hline Maceral Group & Kerogen Type & Grayness & Some of the Macerals in the Group \\
\hline Liptinite & I and II & Dark gray & Alginite, Sporinite, Cutinite, Suberinite, Resinite, Liptodetrinite \\
Vitrinite & III & Medium to light gray & Collotelinite, Vitrodetrinite, Telinite \\
Inertinite & IV & White and can be very bright & Fusinite, Macrinite, Micrinite, Funginite \\
Zooclast & - & Medium to light gray & Graptolite, Scolecodont \\
Secondary products & - & Medium to light gray & Solid bitumen \\
\hline
\end{tabular}

Kerogen constituents' classifications are primarily based on their appearance and preservation states, using transmitted and reflected white light, and their fluorescence emission properties are investigated utilizing the ultraviolet light. These methods examine the kerogen morphology, and emphasis is made on the botanical source, and/or preservation states $[35,36]$.

Under transmitted white light, kerogen can be divided into: Phytoclast group (fragments of tissues derived from higher plants or fungi); palynomorph group (organic-walled microfossils composed of entirely unmineralized proteinaceous material, such as: Chitinozoans, spores and pollen, prasinophytes, acritarchs, and dinoflagellates); zooclast group (faunal relics such as chitinozoans, graptolites, scolecodonts, and conodonts); amorphous group (amorphous organic matter) [36-38]. However, "Solid bitumen" is categorized as another group of organic matter occurring in sedimentary rocks. It is formed after the thermal decomposition of kerogen during the incipient-oil generation 
stage, and then decomposes to oil in the primary-oil generation stage, while, in the post-oil generation phase, the solid bitumen is decomposed to gas or pyrobitumen [35,39].

Incident light microscopy, optical reflectance, and programmed pyrolysis are conventional methods for evaluating the maturity level of the organic matter and a pathway to identify kerogen type $[26,40,41]$. However, these methods become challenging to be utilized on small volumes of OM or when a specific maceral cannot be recognized in the samples [22,42]. Additionally, programmed pyrolysis is a bulk analyzer that merely yields general information about the dominant kerogen type within the samples, and in overmature samples, it is difficult to recognize initial maceral composition from programmed pyrolysis. Thus, programmed pyrolysis is not sensitive to any maceral-specific information about the individual kerogen types within the sample, which means the unique impact of each component to the final result is completely ignored [43]. Thus, to overcome this shortcoming, organic petrography should be utilized to delineate existing types of kerogen macerals in a sample for detailed source rock evaluation. However, this method is exhaustive and requires significant training and expertise. Furthermore, petrographic approaches cannot state whether solid bitumen, as an individual particle, is oil-prone or gas-prone and, more in detail, what the original maceral is that produced the solid bitumen. Therefore, employing more elaborate analytical methods such as Raman spectroscopy (RS) can contribute toward a more accurate maceral characterization at smaller scales for individual OM particles [44-50]. Employing RS has also shown potential to detect the detailed composition of different OM types [22], and the impact of each component on hydrocarbon production by understanding their rate of maturation and their oil and gas proneness $[43,48,49,51]$.

RS operates based on molecular vibrations to reveal the molecular structure of substances, such as the organic matter [52-56] and inorganic minerals [57-59]. In this method, after illuminating the sample surface with laser light, a corresponding spectrum will be generated that comprises some bands as fingerprints that refer to specific chemical structures. Raman spectrometers are easy to use and are commonly equipped with an optical microscope to identify and then analyze specific components in source rocks, including individual recognized macerals or solid bitumen $[43,49-51,60]$. Taking advantage of RS has helped researchers to better understand thermal maturity trends of different organic matters [35,51,59,61-65], and also provides information about their $\mathrm{H} / \mathrm{C}$ ratio (Ferralis et al., 2016) and geochemical and even geomechanical properties [56,66,67].

Based on what is laid out above, the current study aims to employ Raman spectra signals to investigate the potential application of this method on kerogen typing or backtracking to the parent maceral that has produced the studied kerogen particle. This is done based on revealing the chemical structural information of different organic matter including macerals from three types of kerogen and solid bitumen and relating them statistically. Ultimately, based on relationships, the proposed method is applied to solid bitumen solely to investigate if RS can reveal the originating kerogen type that has led to the solid bitumen through thermal maturation. This study is an attempt for more accurate geochemical analysis of source rocks and shale plays for cost-effective exploitation and exploration purposes.

\section{Samples and Measurements}

For this study, samples were retrieved from Penn State Coal Bank, Green River, Eagle Ford, Woodford, and Bakken Formations (Figure 1) to make sure a wide range of maturities and identified kerogen types are included, as shown in Figure 2. Coal samples were retrieved from Penn State Coal bank samples as a set of vitrinite-rich coals of increasing rank from low to high rank A. The Green River Formation is an Eocene-aged geologic formation that has the sedimentation in a group of intermountain lakes in Colorado, Wyoming, and Utah, USA. Samples were retrieved from depths of $12,200$ to $12,280 \mathrm{ft}$ ( $\sim 3718$ to $3743 \mathrm{~m})$ with maturities from $\mathrm{VR}_{\mathrm{O}-\mathrm{Eq}} \sim 1.56$ to 1.59 [43]. The Eagle Ford Shale is a Late Cretaceous sedimentary rock located in Texas, USA. The Eagle Ford is composed of organic matter-rich fossiliferous marine shales and marls with interbedded thin limestones. Samples were retrieved from depths of 7200 to $9100 \mathrm{ft}(\sim 2194$ to $2773 \mathrm{~m})$ with maturities from $\mathrm{VR}_{\mathrm{O}-\mathrm{Eq}} \sim 0.95$ to 1.1 . 
The Woodford Shale covers the state of Oklahoma, USA and is mostly Late Devonian in age with the uppermost part as Early Mississippian [26]. Samples were retrieved from depths of 12,210 to 12,290 ft $\left(\sim 3721\right.$ to $3746 \mathrm{~m}$ ) with maturities from $\mathrm{VR}_{\mathrm{O}-\mathrm{Eq}} \sim 0.55$ to 4.3 . The Bakken Formation is a rock unit from the Late Devonian to Early Mississippian age in the Williston Basin, underlying parts of Montana, North Dakota in USA and Saskatchewan and Manitoba in Canada. This formation consists of three members: Lower shale, middle dolomite, and upper shale. The shales were deposited in relatively deep anoxic marine conditions and samples were retrieved from depths of 5438 to 11,199 ft ( 1657 to $3413 \mathrm{~m}$ ) with maturities from $\mathrm{VR}_{\mathrm{O}-\mathrm{Eq}} \sim 0.38$ to 0.92 [6].

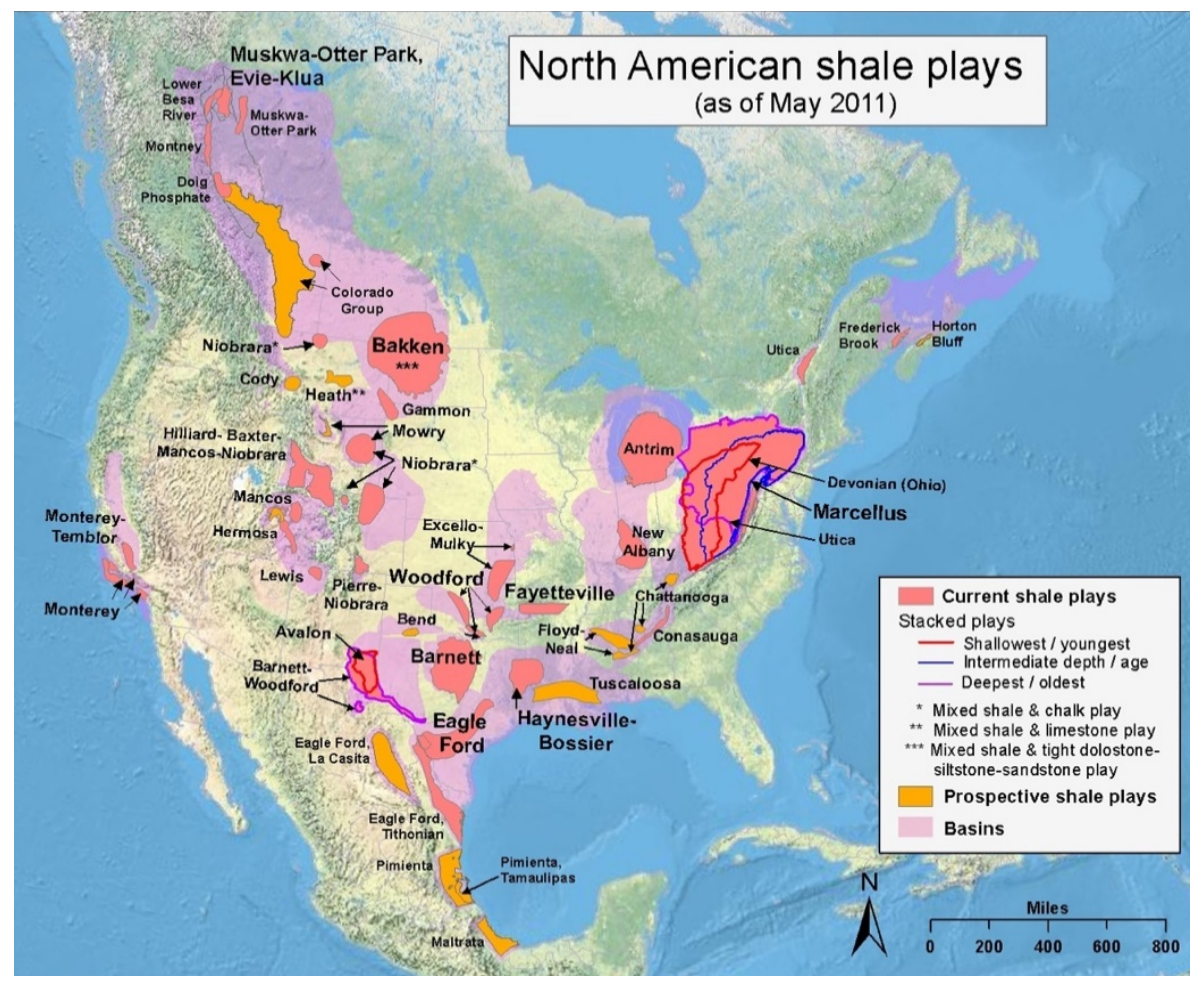

Figure 1. The map of where the samples are retrieved from, showing major shale plays in North America. (Source: USA Energy Information Administration based on data from various studies).
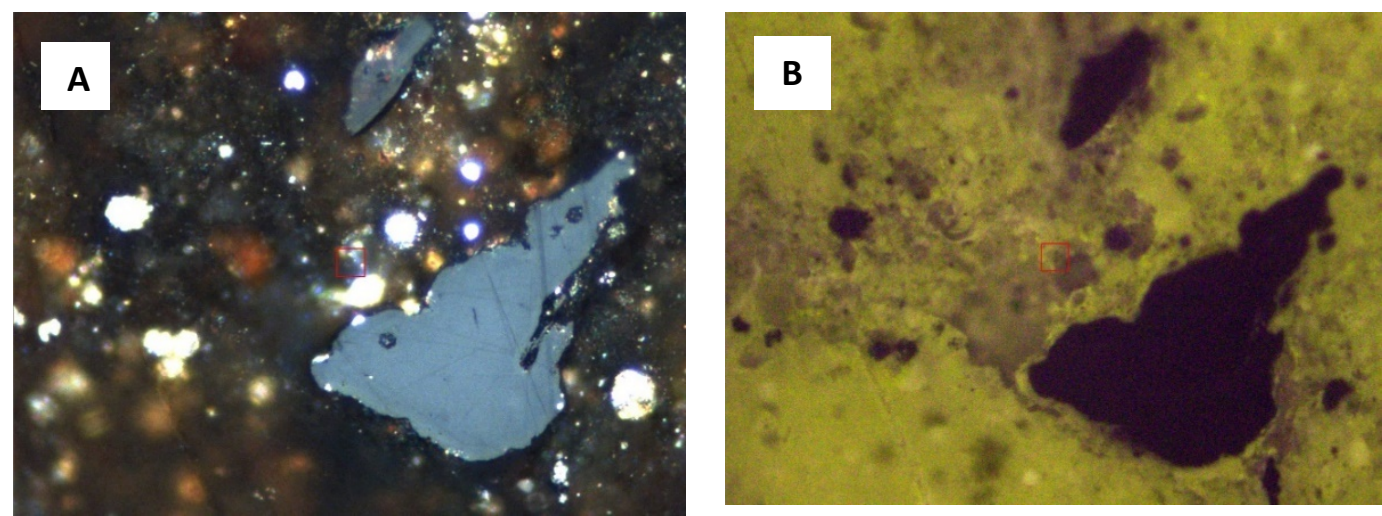

Figure 2. Cont. 



Figure 2. (A) Inertinite particles (gray) in a matrix of amorphous organic matter (AOM); (B) the same view under UV (ultraviolet) light. Inertinite particles have no fluorescence, but the AOM is recognizable 
with yellowish-green fluorescence; (C) inertinite particles (gray) in a matrix of lamellar algal matter and AOM; (D) the same view under UV light.Lamellar algal matter is recognizable by dull yellowish-green fluorescence. Photomicrographs A-D represent Type I and IV kerogens; (E) alginite (Tasmanites) with dull golden yellow fluorescence under UV light; the central suture line is clearly visible; (F) Leiosphaeridia alginite with golden-yellow fluorescence. Photomicrographs E-F represent Type II kerogen; (G) elongated low-reflecting solid bitumen (gray), $\left(\mathrm{SBR}_{\mathrm{O}}\right.$, $\left.\operatorname{ran}=0.27 \%\right)$; $(\mathbf{H})$ solid bitumen, $\left(\mathrm{SBR}_{\mathrm{O}}, \mathrm{ran}=0.40 \%\right)$; photomicrographs $\mathrm{A}-\mathrm{D}$ and $\mathrm{E}-\mathrm{H}$ were taken from the samples of the Green river Formation and the Bakken Formation, respectively, using a 50x oil immersion objective. The red square in the middle of each image is a scale of $5 \mu \mathrm{m}$ of each side. (I,J) Collotelinite and fusinite samples; images are extracted from [43] used in this study.

For organic petrology and reflectance $\left(\% \mathrm{VR}_{\mathrm{O}}\right)$ analysis, the whole-rock samples were crushed to 20 mesh $(850 \mu \mathrm{m})$ particles, mixed with the epoxy resin and hardener, and left to harden under vacuum conditions for $24 \mathrm{~h}[68,69]$. In the next step, at least 30 measurements per sample were acquired following the TSOP/ICCP protocols [15] for reflectance measurements. Bakken samples were also analyzed by the Rock-Eval Basic/Bulk-Rock-programmed pyrolysis method where 15 or $60 \mathrm{mg}$ (depending on reactive kerogen richness as delineated in some research [6,70]) of ground bulk samples were heated isothermally, and the temperature was then increased at a rate of $25^{\circ} \mathrm{C} / \mathrm{min}$ up to $650{ }^{\circ} \mathrm{C}$, in helium carrier gas flowing through the pyrolysis oven. Residual carbon from the previous stage was transferred into the oxygen oven and combusted to obtain the geochemical parameters including $S_{1}$, $\mathrm{S}_{2}, \mathrm{~S}_{3}, \mathrm{~S}_{4}$, and $\mathrm{T}_{\max }$. Using these parameters enables the calculation of hydrogen index (HI), oxygen index (OI), and production index (PI), which can be used for cross-plotting and to create a pseudo-Van Krevelen diagram.

RS operates based on molecular vibrations and symmetries of chemical bonds after excitations with a laser beam to characterize carbonaceous materials [50,63,71-76]. The first-order Raman spectrum $\left(0-1800 \mathrm{~cm}^{-1}\right)$ of kerogen depicts several bands [73,77], Figure 3. The assignment of these bands and the details of what they represent have been studied before [74,78-80] and is summarized in Table 2 . It should be mentioned that the proximity of these recognized bands in terms of their wavenumbers limits the applicability of the RS, which can be resolved by a proper band fitting algorithm to a good level [74].

Table 2. Band assignments for Raman peaks [74,78-80].

\begin{tabular}{|c|c|}
\hline Raman Band Shift & Description of the Band Assignment \\
\hline $\mathrm{G}\left(\right.$ around $1600 \mathrm{~cm}^{-1}$ ) & $\begin{array}{l}\text { - In-plane sp2 bond stretching shear vibration within the aromatic ring in a } \\
\text { large, graphene-like cluster, E2g-Symmetry }\end{array}$ \\
\hline $\mathrm{D}$ (around $1350 \mathrm{~cm}^{-1}$ ) & $\begin{array}{l}\text { - Breathing mode of the sp2 aromatic ring within a graphitic cluster. } \\
\text { - Highly resonant, which means that the optical response is strongly influenced } \\
\text { by the electronic structure of the local environment. } \\
\text { Defect in the aromatic texture (such as vacancies, heteroatoms, } \\
\text { and functional groups) }\end{array}$ \\
\hline D2 (around $1620 \mathrm{~cm}^{-1}$ ) & $\begin{array}{l}\text { - } \quad \text { Corresponds to disordered graphite lattice } \\
\text { - } \quad \text { Shoulder on the G band } \\
\text { - } \quad \text { E2g-Symmetry }\end{array}$ \\
\hline D3 (around $1500 \mathrm{~cm}^{-1}$ ) & $\begin{array}{l}\text { - Amorphous carbon } \\
\text { - } \quad \text { Appear only in very poorly organized carbonaceous material } \\
\text { - } \quad \text { Originates due to interstitial defects outside the plane of aromatic layers }\end{array}$ \\
\hline D4 (around $1150 \mathrm{~cm}^{-1}$ ) & $\begin{array}{l}\text { - Not being currently well understood } \\
\text { - As broad shoulders of the } D \\
\text { - Vibrations of } \mathrm{C}_{\text {aromatic }}-\mathrm{C}_{\text {alkyl; }} \text { aromatic aryl-alkyl ethers, } \mathrm{C}-\mathrm{C} \text { in aromatic rings } \\
\text { and } \mathrm{C}-\mathrm{H} \text { in aromatic rings, as well as trans-polyene-like } \mathrm{C}-\mathrm{C} \text { and } \mathrm{C}=\mathrm{C} \\
\text { stretch bonds }\end{array}$ \\
\hline
\end{tabular}


Table 2. Cont.

\begin{tabular}{lll}
\hline \multicolumn{1}{c}{ Raman Band Shift } & \multicolumn{1}{c}{ Description of the Band Assignment } \\
\hline D5 (around $\left.1265 \mathrm{~cm}^{-1}\right)$ & - $\quad \begin{array}{l}\text { Not being currently well understood } \\
\text { D5 is uniquely related to vibrations originating from aliphatic } \\
\text { hydrocarbon chains } \\
\text { - Disordered graphitic lattice (A1g symmetry), polyenes, ionic impurities }\end{array}$ \\
\hline
\end{tabular}

Raman spectra were acquired from the samples that were prepared for organic petrography by illuminating the surface with a monochromatic laser light of $632.8 \mathrm{~nm}$ in wavelength with approximately $1 \mu \mathrm{m}$ resolution. The power of the laser was $1 \mathrm{~mW}$ ( $1 \%$ of total power), with $1 \mathrm{~s}$ of acquisition time and $3 \mathrm{~s}$ of accumulation, which led to $3 \mathrm{~mW} . \mathrm{s}$ of the energy dumped on the surface of the sample. In terms of spectral precision, the grating (1200 grating $/ \mathrm{mm}$ ) was not moved from one spot to another; therefore, there was no change in the spectral calibration. The instrument was equipped with a $50 \times$ long working distance objective to easily pinpoint the studied OM particle for Raman signal acquisition. To characterize Raman spectral parameters, a curve-fitting step was performed. In this method, the experimental Raman spectrum was reconstructed by deconvolving overlapping peaks in such a manner that the summed spectrum of individual peaks matches the experimental data. To do so, a mixed Gaussian-Lorentzian peak morphology in LabSpec 6 spectroscopy suite (Mark of Horiba Scientific) was used to make sure the best fit was achieved. This method is utilized when both functions are not suitable to reproduce an experimental spectrum. The minimum and maximum width that were allowed for peaks were 10 and $200 \mathrm{~cm}^{-1}$, respectively, and 30 iterations were performed for band picking. Figure 3 shows a representative of the first-order Raman bands related to one of the OM particles that was studied after deconvolution. Ultimately, Table 3 presents the details of the Raman spectra peak decomposition of the samples in this study. It is worth mentioning that in order to remove the long-wavelength function of the fluorescent, a baseline correction using a polynomial order method was also performed.



Figure 3. Schematic of band picking of a Raman spectrum of a representative organic matter (OM) sample of this study. 
Table 3. Information on the sample band spectral shifts.

\begin{tabular}{|c|c|c|c|c|}
\hline $\mathrm{VR}_{\mathrm{O}-\mathrm{Eq}}$ & Type & $\mathrm{D}\left(\mathrm{cm}^{-1}\right)$ & $\mathrm{G}\left(\mathrm{cm}^{-1}\right)$ & D5 $\left(\mathrm{cm}^{-1}\right)$ \\
\hline 1.56 & I (Green river) & 1349 & 1581 & 1225 \\
\hline 1.59 & I (Green river) & 1350 & 1582 & 1223 \\
\hline 0.5 & IIS (undisclosed) & 1377 & 1600 & 1284.8 \\
\hline 2.2 & II (Woodford) & 1349.5 & 1604.3 & 1257 \\
\hline 0.76 & II (Woodford) & 1367 & 1599.7 & 1251 \\
\hline 0.8 & II (Woodford) & 1367 & 1598.7 & 1252.5 \\
\hline 0.55 & II (Woodford) & 1373.5 & 1597.7 & 1257.6 \\
\hline 0.7 & II (Woodford) & 1369.3 & 1597.9 & 1255.4 \\
\hline 0.9 & II (Woodford) & 1361.3 & 1600.9 & 1258.1 \\
\hline 1.55 & II (Woodford) & 1360.7 & 1601.9 & 1260 \\
\hline 4.3 & II (Woodford) & 1340.2 & 1601.9 & 1259 \\
\hline 1.4 & II (Woodford) & 1359.6 & 1602.7 & 1263 \\
\hline 1.4 & II (Woodford) & 1355.4 & 1601 & 1272.3 \\
\hline 0.5 & III (Penn State Coal) & 1353.4 & 1592.2 & 1243.6 \\
\hline 0.69 & III (Penn State Coal) & 1362.4 & 1589.8 & 1251.8 \\
\hline 0.81 & III (Penn State Coal) & 1351.9 & 1590.4 & 1234.9 \\
\hline 1.19 & III (Penn State Coal) & 1352.1 & 1591.1 & 1256.1 \\
\hline 1.6 & III (Penn State Coal) & 1347.5 & 1588.2 & 1259.5 \\
\hline 2 & III (Penn State Coal) & 1346.2 & 1591.7 & 1252.1 \\
\hline 4 & III (Penn State Coal) & 1325.8 & 1596.5 & 1241.7 \\
\hline 0.92 & Solid bitumen (Bakken) & 1354 & 1594 & 1260 \\
\hline 0.94 & Solid bitumen (Bakken) & 1361 & 1603 & 1265 \\
\hline 0.86 & Solid bitumen (Bakken) & 1358 & 1593.5 & 1263 \\
\hline 0.54 & Solid bitumen (Bakken) & 1367 & 1601 & 1269 \\
\hline 0.38 & Solid bitumen (Bakken) & 1361 & 1593.5 & 1274 \\
\hline 0.59 & Solid bitumen (Bakken) & 1361 & 1593 & 1263 \\
\hline 0.71 & Solid bitumen (Bakken) & 1365 & 1601 & 1270 \\
\hline 1.08 & Solid bitumen (Bakken) & 1362 & 1605.5 & 1275 \\
\hline 1.09 & Solid bitumen (Bakken) & 1360 & 1603.5 & 1268.5 \\
\hline 0.91 & Solid bitumen (Bakken) & 1365 & 1605 & 1259 \\
\hline 0.95 & III (Eagle ford) & 1354 & 1578 & 1255 \\
\hline 0.98 & III (Eagle ford) & 1353 & 1582 & 1256 \\
\hline 1.1 & III (Eagle ford) & 1350 & 1586 & 1248 \\
\hline NA & Solid bitumen (Eagle Ford) & 1357 & 1575 & 1248 \\
\hline NA & Solid bitumen (Eagle Ford) & 1362 & 1574 & 1253 \\
\hline NA & Solid bitumen (Eagle Ford) & 1360 & 1576 & 1260 \\
\hline
\end{tabular}

\section{Results and Discussion}

\subsection{Raman Spectroscopy and Maturity}

The molecular structure of $\mathrm{OM}$ has a strong correlation with its maturity level from the fictional group variation stand point. Previous studies have documented systematic changes in the structure of the OM by RS (band positions, band separation, FWHM, etc.) as a function of maturity advancement $[56,63,66,67,74,81]$. When kerogen advances toward higher maturities, its aromaticity will increase and, in this process, the macromolecule breaks down and loses its $\mathrm{O}, \mathrm{N}$, and $S$ content $[63,82]$, which can be detected by the Raman response. Figure 4 depicts the correlation between the separation of two major Raman bands (G-D) versus equivalent vitrinite (VR-Eq $)$ maturity of the samples retrieved from different formations. The increase in the band separation with maturity is attributed to the shift in the D band toward lower wavenumbers with a minor change in the $G$ band toward higher wavenumbers. Moreover, at lower maturity levels, band separation changes at a higher rate; however, toward the higher levels of thermal maturity, the rate decreases and the separation of the G-D bands gradually tapers off. This can be interpreted as the advancement to a more homogenous $\mathrm{OM}$. This happens because by increasing the maturity, $\mathrm{H} / \mathrm{C}$ and $\mathrm{O} / \mathrm{C}$ ratios decrease 
and the final composition of the OM approaches the pure carbon (graphite), which can be reflected by minor changes in band separation [83].

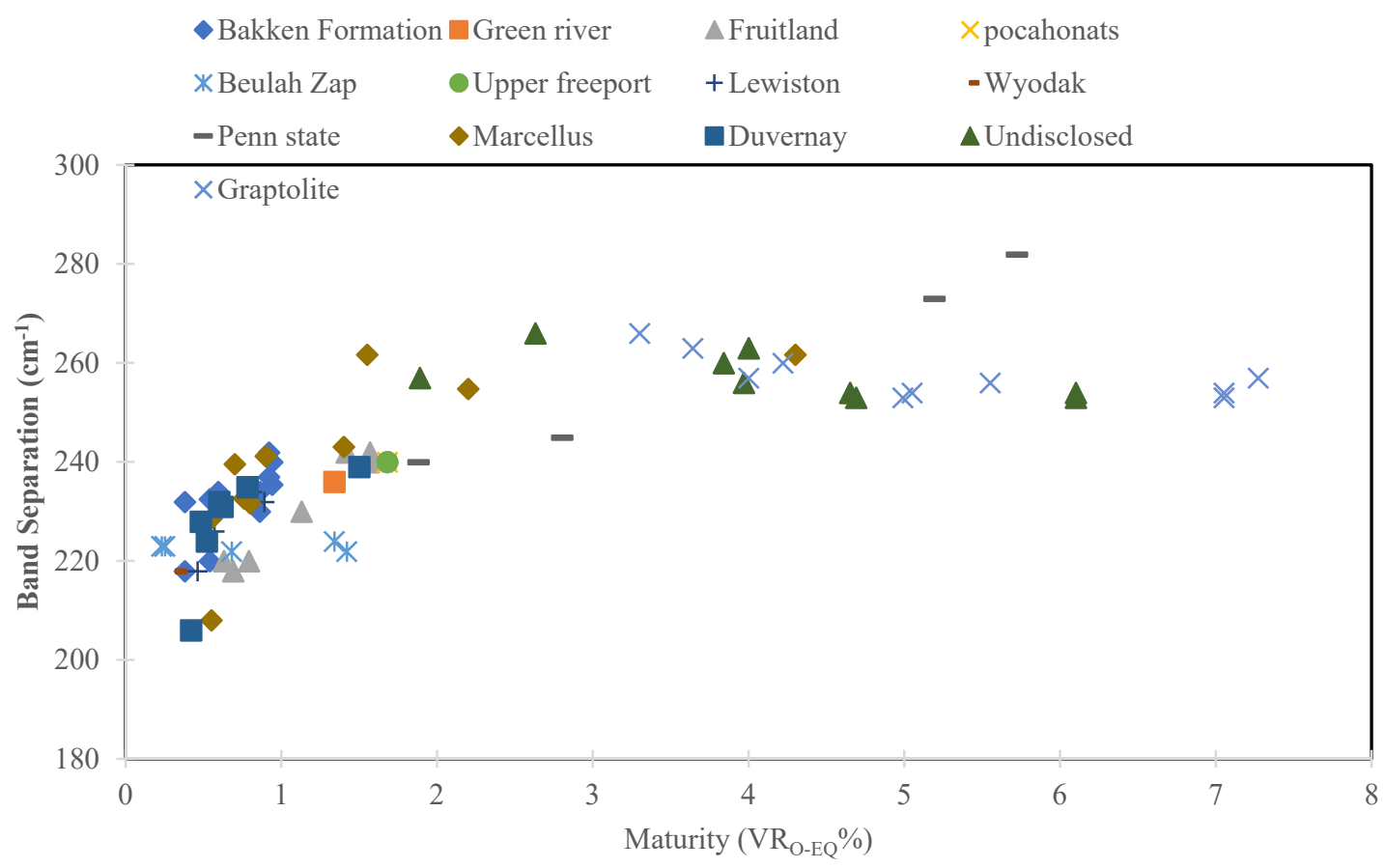

Figure 4. Raman band separation (G-D) vs. maturity (VR $\mathrm{O}-\mathrm{Eq} \%$ ) for 13 samples from different geologic regions including the Bakken Formation, Green River, Penn State, Marcellus, Duvernay, and undisclosed Formations. (Data are extracted from other research $[64,67,81]$ acquired by the $532 \mathrm{~nm}$ laser wavelength).

We also plotted each maceral's reflectance versus G-D band separation to better delineate the existence of different chemical information in our samples, Figure 5. As each OM in this graph should have different maceral origins and, consequently, different physico-chemical properties, they demonstrate various rates of band separation vs. maturity as they progress toward aromatization [50]. This phenomenon is represented by the slope of the curves that is fitted through the data for each group of macerals. As seen in Figure 5, fusinite and macrinite (Type IV kerogen) show similar trends in the curves. This similarity can be related to the fact that, fundamentally, both of them are derived from the same origin (plants) and result from the decay path before or during peatification $[43,84,85]$. Collotelinite and another (undisclosed) Type III kerogen also demonstrate similar trends. Graptolites (zooclasts) and Type II (unknown maceral) kerogen, even though from different origins, have similar slopes, which is in agreement with the Raman studies of previous studies $[50,86]$.

At the same level of thermal maturity, the general existing fraction of aromatic carbon in kerogen has the order of: Type IV > Type III > Type II $[17,25,82,87]$, which is exactly opposite the slopes seen in Figure 5. It can be described that the rate of maturation of different organic matters would differ and result in a varying rate of band separation. This varying maturity rate is equivalent to different rates (which corresponds to different slopes in the figures) of advancement toward higher aromaticity levels in each kerogen type or OM particle. Furthermore, researchers have also documented that at the same maturity level, the reflectance of kerogens types is on the order of Type IV > Type III > Type II prior to converting the reflectance values to the equivalent vitrinite reflectance [88-90]. This has been inferred to be due to different aromaticity levels of various kerogen types and OM [31,91,92]. Therefore, slopes of different organic matter in Figure 5 represent the macromolecular aromatic components of $\mathrm{OM}$, which also confirms their optical characteristics. 
Type II

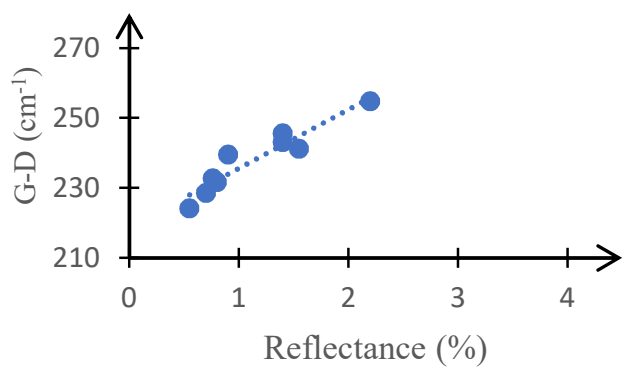

- Type II (undisclosed)

$\mathrm{y}=16.828 \mathrm{x}+218.76$.

Type IV



OMacrinite

- Fusunite
Type III

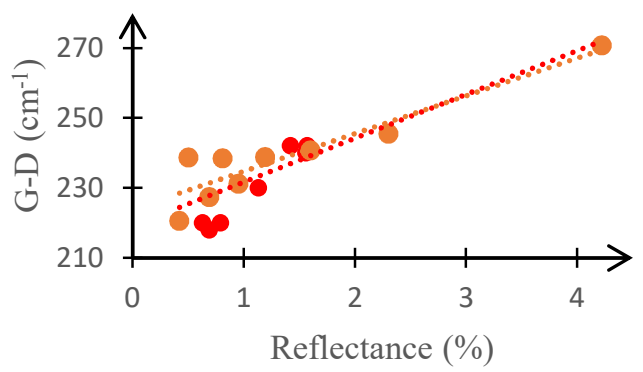

- Maceral Type III kerogen Collotelinite

$y=12.512 x+219.26$

Zooclasts



- Graptolite

$y=17.072 x+231.06$

$y=6.5062 x+246.68$

Solid bitumen

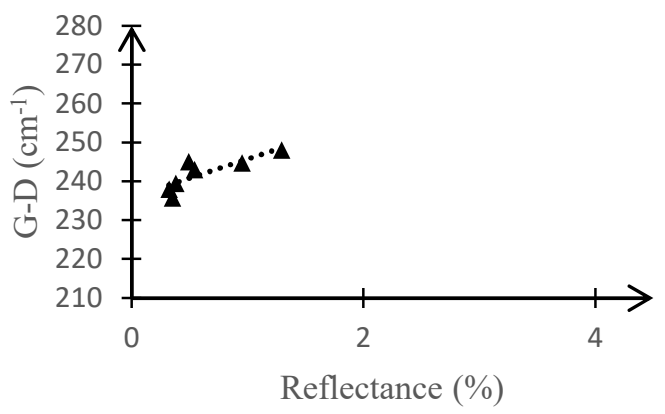

$\Delta$ Solid bitumen

$y=9.9155 x+235.88$

Figure 5. Comparison of band separation and reflectance of several OM types. Data are extracted from other researches $[43,50,63]$ acquired by the $632 \mathrm{~nm}$ laser wavelength.

It is worth mentioning in such studies it is very important to consider the laser wavelength used while acquiring Raman spectra. Therefore, different laser wavelength cannot be compared, since peak position and intensity for carbonaceous materials is strongly dependent on the laser source. 


\subsection{Raman Spectroscopy and Kerogen Typing}

Each kerogen type comprises a set of macerals that share almost similar physical and chemical properties $[93,94]$, which make them more closely related compared to macerals from other kerogen types [1]. Based on this idea, RS as a tool that provides insight to study molecular structures through vibrational methods (a physical characteristic related to chemical structure) should have the potential in separating various types of kerogen and delineating the pathway of OM overall evolution.

To do so, we plotted different existing bands (wavenumbers) against one another from the studied samples and realized, among all, that the G (vibration within the aromatic ring) band vs. D5 (vibrations originating from aliphatic hydrocarbon chains) displayed a good distinction of different kerogen types, Figure 6, which was in accordance with previous research [22]. Based on the position of each kerogen type in this diagram, it can be inferred that the sulfur (S) content of the studied OMs is playing a key role in the separation of various kerogen types. Table 4 explains the average elemental composition of immature kerogens reported by another study [95]. It can be found that type II kerogen has the highest sulfur content, type I the least, and type III in between [35,96], which follows the trend seen in Figure 6. Lacustrine environments yield kerogens, which are relatively depleted in S, while marine environments based on anoxic/euxinic conditions and mineralogy result in kerogens with varying amounts of organic S [97]. Type II-S kerogen contains a higher amount of S (8-14 wt\%) compared to other kerogen types and is derived from autochthonous OM in highly reducing conditions in a marine environment, which is mostly associated with upwelling conditions [95,98]. As seen in Figure 6, type II-S is located at the far right region of this graph representing the OM with the highest sulfur content.

The D5 band has been uniquely related to vibrations originating from aliphatic hydrocarbon chains [74]. Li et al. [79] utilized light-element electron microprobe (EMP) and micro-ATR-FTIR to study macerals in bituminous coals with variable organic sulfur content from different geographic locations. This study argues that the higher organic $S$ content in the maceral appears to be accompanied by a greater proportion of aliphatic functional groups, as a result of the replacement of some of the oxygen $(\mathrm{O})$ within the maceral in ring structures with sulfur $(\mathrm{S})$. This can explain the trend that is observed in Figure 6, where kerogens with higher sulfur content (corresponds to a greater proportion of aliphatic functional groups) exhibit higher D5 values. Moreover, Kelemen et al. [97] used X-ray photon spectroscopy (XPS) and sulfur X-ray absorption near edge structure (S-XANES) to analyze a wide range of organic matter types and maturities. They detected that when the amount of aromatic carbon is increased, aliphatic sulfur declines for all kerogen types. This idea can also corroborate the distribution trend of macerals in the changing format from the upper left to lower right regions in this plot. The G band is purely of aromatic character [74] and the shift in the G band toward higher wave numbers by increasing aromaticity has also been observed by others $[50,63]$. Thus, when the $G$ band wavenumber is increased (shifting toward the upper left region of the graph for each kerogen type that is separated), the D5 wavenumber would decrease, which can be associated with a decrease in aliphatics (sulfur).

Table 4. Average elemental composition of $\mathrm{C}, \mathrm{H}, \mathrm{O}, \mathrm{S}$, and $\mathrm{N}$ in kerogen [95].

\begin{tabular}{cccccc}
\hline Kerogen Type & \%Carbon & \%Hydrogen & \%Oxygen & \%Sulfur & \%Nitrogen \\
\hline Type I & 80 & 10.9 & 4.9 & 1.3 & 1.6 \\
Type II & 68.9 & 7.3 & 6.6 & 10.6 & 1.5 \\
Type III & 56.2 & 4.4 & 27.8 & 2.4 & 1.6 \\
\hline
\end{tabular}






Figure 6. G vs. D5 is important for kerogen typing. As seen, different types of kerogen are located on this graph based on what is expected from their sulfur content (Type II > Type III > Type I) (numbers reflect thermal maturity of the samples). (Data are from this study acquired by the $632 \mathrm{~nm}$ laser wavelength).

As mentioned earlier, solid bitumen is a secondary product, which is not categorized under any kerogen type, while it is a product of any type of kerogen (I, II, or III) conversion through the thermal maturity or petroleum de-asphalting process [34]. Therefore, it is expected that any solid bitumen based on the parent maceral will somehow display similar physicochemical properties to a particular type of kerogen that it is basically originating from. The gas/oil proneness of solid bitumen, which explains its hydrocarbon generation potential, and its role in thermal maturity evaluation, make solid bitumen an important particle in unconventional organic-liquid-rich shale plays [34,99-102]. However, organic petrography is inadequate for accurately detecting gas/oil proneness and incapable of relating the identified solid bitumen particle to its parent maceral. In order to investigate if the results from this study that was performed on macerals can be extended to solid bitumen and reveal the kerogen type that specific solid bitumen originates from, we utilized samples from the Bakken and Eagle Ford Shale Formations and examined solid bitumen particles that were identified to acquire their Raman spectra. G and D5 bands from the studied solid bitumen particles are overlaid on the same plot as Figure 6 and presented in Figure 7. It is observed that two separate solid bitumen populations are delineated, which indicates properties similar to two different types of kerogen. This can be supported by the fact that solid bitumen is a product of OM transformation. Furthermore, authors believe that the positioning of different solid bitumens in this plot is more related to their $\mathrm{G}$ bands rather than the changes in the D5 band.

Figure 8 is the pseudo-Van Krevelen diagram from the bulk analysis of shale samples from the Bakken Formation, pointing to type II as the dominant kerogen type in the samples with which Raman spectroscopy was used to examine their solid bitumen. Bulk analysis such as programmed pyrolysis will describe the relative abundance of kerogen types. However, considering solid bitumen as the predominant organic matter in the late oil to dry gas window [26,32-34], it is reasonable to assume that programmed pyrolysis reflects properties of the solid bitumen relevant to type II kerogen, mostly, from which it has been originating, while solid bitumen from Eagle Ford presents properties similar to type III kerogen, enforcing the separation of the data between these two studied solid bitumen particles. Therefore, we can propose that utilizing RS is able to detect the parent kerogen of the existing solid bitumen in the samples. 
The results can also explain the difference in the trends between some of the major equations that have been introduced to convert solid bitumen reflectance to $\mathrm{VR}_{\mathrm{O}-\mathrm{Eq}}$ in the literature. These equations are developed from measurements on solid bitumen that are the product of various types of kerogen conversion through thermal maturity, and, therefore, discrepancies should be expected.

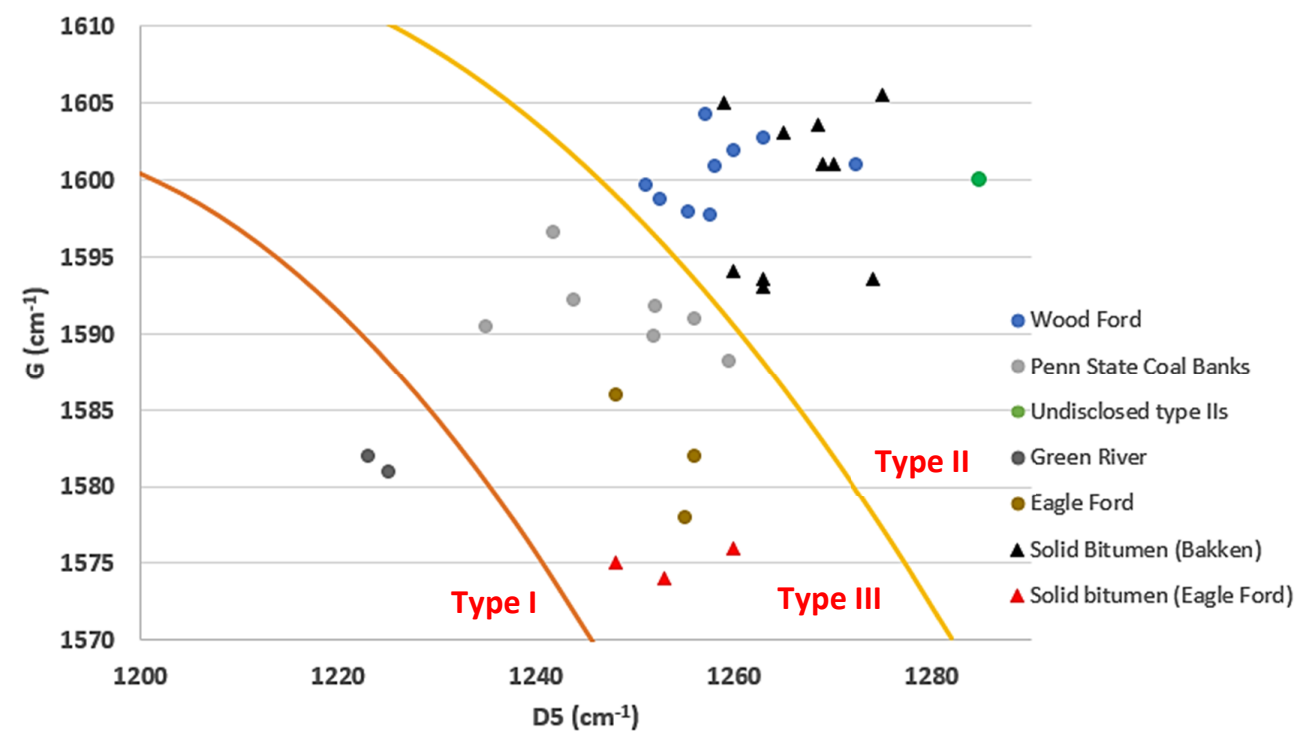

Figure 7. G vs. D5 for kerogen typing. Solid bitumen samples are also shown in this figure. As seen, solid bitumen populations can show different characters. Data points are the same as Figure 6, except for the red and black triangles that represent solid bitumen from the Eagle Ford and Bakken, respectively. Data acquired in this study with the $632 \mathrm{~nm}$ laser wavelength.

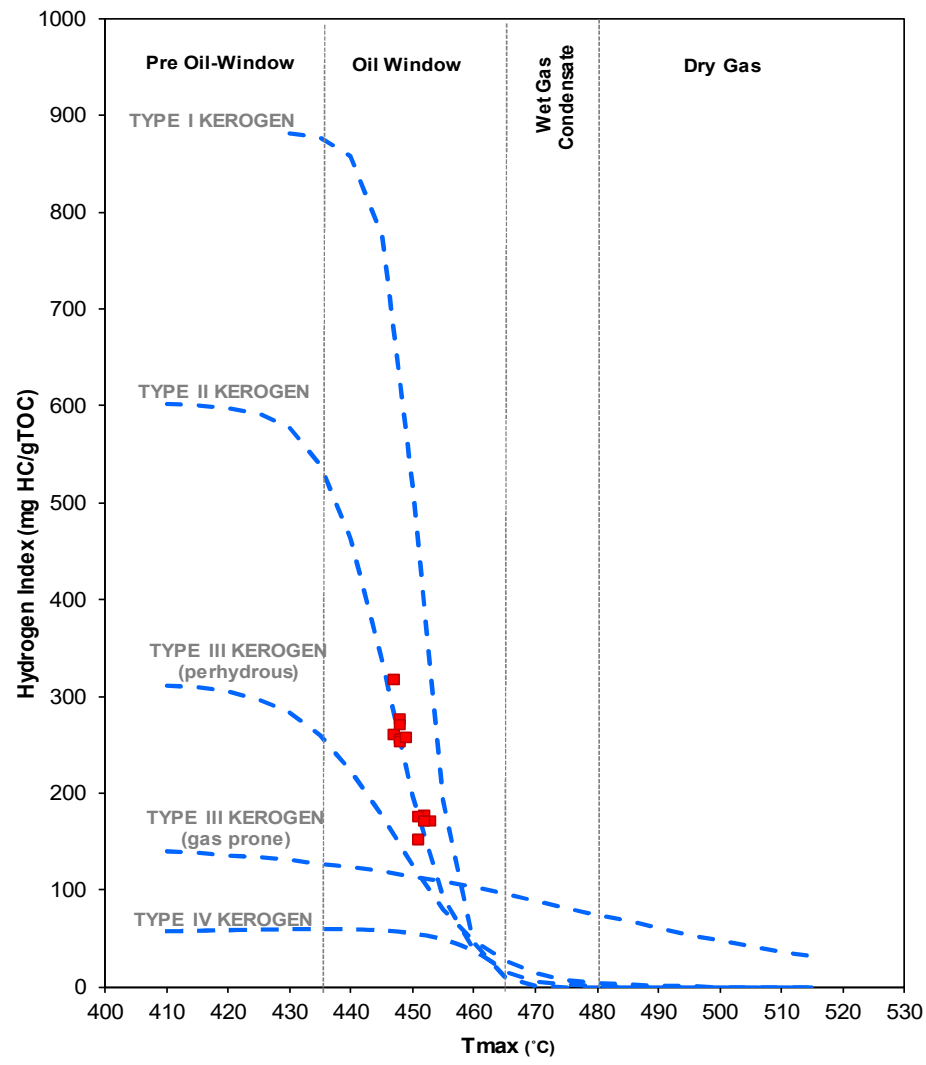

Figure 8. Hydrogen index vs. $\mathrm{T}_{\max }$ for kerogen typing using Rock-Eval parameters for the Bakken Samples.4. Conclusion. 
Bulk analyses such as programmed pyrolysis on OM can provide general information without considering the impact of each component on the result. In this study, by employing RS as a well-known tool for studying carbonaceous materials, the potential of kerogen typing using Raman signals was investigated, which benefits from being applicable directly to embedded OM particles in sediments (no need for kerogen isolation) in a fast and accurate way without high labor cost.

Results showed that plotting the peak position of the G band vs. D5 will distinguish different kerogen types based on their aromaticity level and sulfur content. In the next step, the proposed method was performed on solid bitumen samples to support the idea of different behaviors and multiple populations of solid bitumen in shale rocks, which can lead to a new path to further studies on solid bitumen as one of the key components in shale plays and source rocks as hydrocarbon generators, thermal maturity indicators, and hydrocarbon storage and migration.

Author Contributions: Conceptualization, M.O.; methodology, M.O. and S.K.; software, S.K.; validation, M.O., K.L., A.A., A.G. and B.V.; formal analysis, S.K., A.A., K.L., A.G. and B.V.; investigation, S.K., M.O., K.L., A.A., A.G. and B.V.; resources, M.O., A.G. and B.V.; data curation, S.K., A.A., K.L., A.G. and B.V.; writing-original draft preparation, S.K. and A.A.; writing—review and editing, M.O., A.G. and B.V.; visualization, S.K., A.A., K.L.; supervision, M.O.; project administration, M.O.; funding acquisition, M.O. All authors have read and agreed to the published version of the manuscript.

Funding: This research received no external funding.

Acknowledgments: The authors wish to thank the North Dakota Geological Survey, Core Library, for giving us access to the Bakken core samples, particularly Jeffrey Bader, senior state geologist and the director, as well as Kent Hollands, lab technician. Moreover, we'd like to express sincere appreciation to David Tuschel from Horiba Scientific for his oversight during data collection, providing us with the Raman equipment and fruitfil discussion and input. Last but not least, the rigorous review process and comments from two respected reviewers and the editor that significantly improved the quality of this manuscript is very much appreciated.

Conflicts of Interest: The authors declare no conflict of interest.

\section{References}

1. Hutton, A.; Bharati, S.; Robl, T. Chemical and petrographic classification of kerogen/macerals. Energy Fuels 1994, 8, 1478-1488. [CrossRef]

2. Vandenbroucke, M.; Largeau, C. Kerogen origin, evolution and structure. Org. Geochem. 2007, 38, 719-833. [CrossRef]

3. Tissot, B.; Welte, D. Petroleum Formation and Occurrence: A New Approach to Oil and Gas Exploration; Springer Science \& Business Media: Berlin/Heidelberg, Germany, 2012.

4. Waples, D.W. Geochemistry in Petroleum Exploration; Springer Science \& Business Media: Berlin/Heidelberg, Germany, 2013.

5. Peters, K. Guidelines for evaluating petroleum source rock using programmed pyrolysis. AAPG Bull. 1986, 70, 318-329.

6. Abarghani, A.; Ostadhassan, M.; Gentzis, T.; Carvajal-Ortiz, H.; Ocubalidet, S.; Bubach, B.; Mann, M.; Hou, X. Correlating Rock-Eval ${ }^{\mathrm{TM}}$ Tmax with bitumen reflectance from organic petrology in the Bakken Formation. Int. J. Coal Geol. 2019, 205, 87-104. [CrossRef]

7. Spackman, W.; Moses, R.G. Nature and Occurrence of Ash Forming Minerals in Anthracite; No. SR-22; Department of Geology, University Park (USA), Pennsylvania State University: State College, PA, USA, 1960.

8. Teichmuller, M.; Teichmuller, R. Stach's Textbook of Coal Petrology; Gebruder Borntraeger: Stuttgart, Germany, 1982.

9. Styan, W.B.T.; Bustin, R.M. Petrographyof some fraser river delta peat deposits: Coal maceral and microlithotype precursors in temperate-climate peats. Int. J. Coal Geol. 1983, 2, 321-370. [CrossRef]

10. Teichmüller, M. The genesis of coal from the viewpoint of coal petrology. Int. J. Coal Geol. 1989, 12, 1-87. [CrossRef]

11. International, Committee for Coal and Organic Petrology. The new vitrinite classification (ICCP System 1994). Fuel 1998, 77, 349-358. [CrossRef]

12. International, Committee for Coal and Organic Petrology. The new inertinite classification (ICCP System 1994). Fuel 2001, 80, 459-471. [CrossRef] 
13. Taylor, G.H.; Teichmüller, M.; Davis, A.C.F.K.; Diessel, C.F.K.; Ralf, L.; Paul, R. Organic Petrology; Borntraeger: Berlin-Stuttgar, Germany, 1998.

14. ISO-7404/5.2009. Methods for the Petrographic Analysis of Coals. Part 5: Method of Determining Microscopically the Reflectance of Vitrinite. 2009. Available online: https://www.iso.org/standard/42832.html (accessed on 27 July 2020).

15. American Society for Testing and Materials (ASTM). Standard test method for microscopical determination of the reflectance of vitrinite dispersed in sedimentary rocks. Pet. Prod. Lubr. Fossil Fuels gaSeous Fuels Coal Coke 2014, 823-830. [CrossRef]

16. Pickel, W.; Kus, J.; Flores, D.; Kalaitzidis, S.; Christanis, K.; Cardott, B.J.; Misz-Kennan, M.; Crosdale, P.; Wagner, N.; ICCP. Classification of liptinite-ICCP System 1994. Int. J. Coal Geol. 2017, 169, 40-61. [CrossRef]

17. Lis, G.P.; Mastalerz, M.; Schimmelmann, A.; Lewan, M.D.; Artur Stankiewicz, B. FTIR absorption indices for thermal maturity in comparison with vitrinite reflectance R0 in type-II kerogens from Devonian black shales. Org. Geochem. 2005, 36, 1533-1552. [CrossRef]

18. Abarghani, A.; Gentzis, T.; Shokouhimehr, M.; Liu, B.; Ostadhassan, M. Chemical heterogeneity of organic matter at nanoscale by AFM-based IR spectroscopy. Fuel 2020, 261, 116454. [CrossRef]

19. Lafargue, E.; Marquis, F.; Pillot, D. Rock-Eval 6 applications in hydrocarbon exploration, production, and soil contamination studies. Revue de l'institut Français du Pétrole 1998, 53, 421-437. [CrossRef]

20. Behar, F.; Beaumont, V.; De Penteado, H.L.B. Rock-Eval 6 technology: Performances and developments. Oil Gas Sci. Technol. 2001, 56, 111-134. [CrossRef]

21. Kultaransingh, H.; Hathon, L.; Dixon, M.; Myers, M. Organic matter characterization in shales: A systematic empirical protocol. Micros. Microanal. 2017, 23, 2130-2131.

22. Liu, Z.; Hathon, L.A.; Myers, M.T. Characterization of thermal maturity and organic material type With Raman Spectroscopy in shale reservoirs. In Proceedings of the SPWLA 58th Annual Logging Symposium, Oklahoma City, OK, USA, 17-21 June 2017; Society of Petrophysicists and Well-Log Analysts: Houston, TX, USA, 2017.

23. John, R.; Nicholas, P. Cheremisinoff. Gasification Technologies: A Primer for Engineers and Scientists; CRC Press: Boca Raton, FL, USA, 2005.

24. Chaudhuri, S.N. Coal Macerals. Encycl. Miner. Energy Policy 2016, 1-5.

25. Peters, K.E.; Walters, C.C.; Moldowan, J.M. The Biomarker Guide. Volume 2: Biomarkers and Isotopes in the Environment and Human History; Cambridge University Press: Cambridge, UK, 2005; Volume 75, p. 76.

26. Hackley, P.C.; Cardott, B.J. Application of organic petrography in North American shale petroleum systems: A review. Int. J. Coal Geol. 2016, 163, 8-51. [CrossRef]

27. Cardott, B.J.; Kidwai, M.A. Graptolite reflectance as a potential thermal-maturation indicator. Okla. Geol. Surv. Circ. 1991, 92, 203-209.

28. Suárez-Ruiz, I.; Flores, D.; Filho, J.G.M.; Hackley, P.C. Review and update of the applications of organic petrology: Part 1, geological applications. Int. J. Coal Geol. 2012, 99, 54-112. [CrossRef]

29. Jacob, H. Classification, structure, genesis and practical importance of natural solid oil bitumen ("migrabitumen"). Int. J. Coal Geol. 1989, 11, 65-79. [CrossRef]

30. Bertrand, R.; Malo, M. Source rock analysis, thermal maturation and hydrocarbon generation in Siluro-Devonian rocks of the Gaspe Belt basin, Canada. Bull. Can. Pet. Geol. 2001, 49, 238-261. [CrossRef]

31. Mählmann, R.F.; Frey, M. Standardisation, calibration and correlation of the Kübler-index and the vitrinite/bituminite reflectance: An inter-laboratory and field related study. Swiss J. Geosci. 2012, 105, 153-170.

32. Daniel, R.; Littke, R.; Bruns, B.; Mahlstedt, N. Organic Geochemistry and petrography of Lower Cretaceous Wealden black shales of the Lower Saxony Basin: The transition from lacustrine oil shales to gas shales. Org. Geochem. 2013, 63, 18-36.

33. Danielle, K.; Sanei, H.; Embry, A.; Ardakani, O.H.; Clarkson, C.R. Depositional environment and hydrocarbon potential of the Middle Triassic strata of the Sverdrup Basin, Canada. Int. J. Coal Geol. 2015, 147, 71-84.

34. Mastalerz, M.; Drobniak, A.; Stankiewicz, A.B. Origin, properties, and implications of solid bitumen in source-rock reservoirs: A review. Int. J. Coal Geol. 2018, 195, 14-36. [CrossRef]

35. Tissot, B.P.; Dietrich, H.W. From kerogen to petroleum. In Petroleum Formation and Occurrence; Springer: Berlin/Heidelberg, Germany, 1984; pp. 160-198. 
36. Tyson, R.V. Palynological kerogen classification. In Sedimentary Organic Matter; Springer: Dordrecht, The Netherlands, 1995; pp. 341-365.

37. Vincent, A.J. Palynofacies Analysis of Middle Jurassic Sediments from the Inner Hebrides. Ph.D. Thesis, Newcastle University, Newcastle upon Tyne, UK, 1995.

38. Mendonça Filho, J.G. Aplicação de estudos de palinofácies e fácies orgânica em rochas do Paleozóico da Bacia do Paraná, Sul do Brasil. Universidade Federal do Rio Grande do Sul. Tese de Doutorado 1999, 2, 338.

39. Lewan, M.D. Laboratory simulation of petroleum formation. In Organic Geochemistry; Springer: Boston, MA, USA, 1993; pp. 419-442.

40. Thomas, G.; Carvajal-Ortiz, H.; Tahoun, S.; Li, C.; Ostadhassan, M.; Xie, H.; Filho, J.G.M. A Multi-Component Approach to Study the Source-Rock Potential of the Bakken Shale in North Dakota, USA, Using Organic Petrology, Rock-Eval Pyrolysis, Palynofacies, LmPy-GCMSMS Geochemistry, and NMR Spectroscopy. 2017. Available online: http://archives.datapages.com/data/tsop/tsopv34-2017/gentzis.htm (accessed on 27 July 2020).

41. Thomas, G.; Carvajal-Ortiz, H.; Ocubalidet, S.G.; Wawak, B. Organic Petrology Characteristics of Selected Shale Oil and Shale Gas Reservoirs in the USA: Examples from "The Magnificent Nine”. In Geology: Current and Future Developments: The Role of Organic Petrology in the Exploration of Conventional and Unconventional Hydrocarbon Systems; Bentham Science Publishers: Sharjah, UAE, 2017; Volume 1, pp. 131-168.

42. Houseknecht, D.W.; Bensley, D.F.; Hathon, L.A.; Kastens, P.H. Rotational reflectance properties of Arkoma Basin dispersed vitrinite: Insights for understanding reflectance populations in high thermal maturity regions. Org. Geochem. 1993, 20, 187-196. [CrossRef]

43. Guedes, A.; Valentim, B.; Prieto, A.C.; Rodrigues, S.; Noronha, F. Micro-Raman spectroscopy of collotelinite, fusinite and macrinite. Int. J. Coal Geol. 2010, 83, 415-422. [CrossRef]

44. Mastalerz, M.; Marc Bustin, R. Application of reflectance micro-Fourier transform infrared spectrometry in studying coal macerals: Comparison with other Fourier transform infrared techniques. Fuel 1995, 74, 536-542. [CrossRef]

45. Mastalerz, M.; Marc Bustin, R. Electron microprobe and micro-FTIR analyses applied to maceral chemistry. Int. J. Coal Geol. 1993, 24, 333-345. [CrossRef]

46. Ward, C.R.; Gurba, L.W. Chemical composition of macerals in bituminous coals of the Gunnedah Basin, Australia, using electron microprobe analysis techniques. Int. J. Coal Geol. 1999, 39, 279-300. [CrossRef]

47. Marqués, M.; Suárez-Ruiz, I.; Flores, D.; Guedes, A.; Rodrigues, S. Correlation between optical, chemical and micro-structural parameters of high-rank coals and graphite. Int. J. Coal Geol. 2009, 77, 377-382. [CrossRef]

48. Wilkins, R.W.T.; Diessel, C.K.F.; Buckingham, C.P. Comparison of two petrographic methods for determining the degree of anomalous vitrinite reflectance. Int. J. Coal Geol. 2002, 52, 45-62. [CrossRef]

49. Guedes, A.; Valentim, B.; Prieto, A.C.; Noronha, F. Raman spectroscopy of coal macerals and fluidized bed char morphotypes. Fuel 2012, 97, 443-449. [CrossRef]

50. Mumm, A.S.; İnan, S. Microscale organic maturity determination of graptolites using Raman spectroscopy. Int. J. Coal Geol. 2016, 162, 96-107. [CrossRef]

51. Guedes, A.; Noronha, F.; Carmelo Prieto, A. Characterisation of dispersed organic matter from lower Palaeozoic metasedimentary rocks by organic petrography, X-ray diffraction and micro-Raman spectroscopy analyses. Int. J. Coal Geol. 2005, 62, 237-249. [CrossRef]

52. Beyssac, O.; Goffé, B.; Chopin, C.; Rouzaud, J.N. Raman spectra of carbonaceous material in metasediments: A new geothermometer. J. Metamorph. Geol. 2002, 20, 859-871. [CrossRef]

53. Beyssac, O.; Goffé, B.; Petitet, J.-P.; Froigneux, E.; Moreau, M.; Rouzaud, J.-N. On the characterization of disordered and heterogeneous carbonaceous materials by Raman spectroscopy. Spectrochim. Acta Part A Mol. Biomol. Spectrosc. 2003, 59, 2267-2276. [CrossRef]

54. Hinrichs, R.; Brown, M.T.; Vasconcellos, M.A.Z.; Abrashev, M.V.; Kalkreuth, W. Simple procedure for an estimation of the coal rank using micro-Raman spectroscopy. Int. J. Coal Geol. 2014, 136, 52-58. [CrossRef]

55. Schito, A.; Romano, C.; Corrado, S.; Grigo, D.; Poe, B. Diagenetic thermal evolution of organic matter by Raman spectroscopy. Org. Geochem. 2017, 106, 57-67. [CrossRef]

56. Khatibi, S.; Ostadhassan, M.; Tuschel, D.; Gentzis, T.; Carvajal-Ortiz, H. Evaluating molecular evolution of kerogen by Raman Spectroscopy: Correlation with optical microscopy and rock-eval pyrolysis. Energies 2018, 11, 1406. [CrossRef]

57. Griffith, W.P. Raman spectroscopy of minerals. Nature 1969, 224, 264. [CrossRef] 
58. Bersani, D.; Lottici, P.P. Raman spectroscopy of minerals and mineral pigments in archaeometry. J. Raman Spectrosc. 2016, 47, 499-530. [CrossRef]

59. Tuschel, D. Raman spectroscopy of oil shale. Spectroscopy 2013, 28, 20-27.

60. Wilkins, R.W.T.; Boudou, R.; Sherwood, N.; Xiao, X. Thermal maturity evaluation from inertinites by Raman spectroscopy: The 'RaMM'technique. Int. J. Coal Geol. 2014, 128, 143-152. [CrossRef]

61. Waples, D.W. Organic Geochemistry for Exploration Geologists; Burgess Pub. Co.: Minneapolis, MN, USA, 1981.

62. Ferrari, A.C.; Robertson, J.F. Interpretation of Raman spectra of disordered and amorphous carbon. Phys. Rev. B 2000, 61, 14095. [CrossRef]

63. Kelemen, S.R.; Fang, H.L. Maturity trends in Raman spectra from kerogen and coal. Energy Fuels 2001, 15, 653-658. [CrossRef]

64. Sauerer, B.; Craddock, P.R.; AlJohani, M.D.; Alsamadony, K.L.; Abdallah, W. Fast and accurate shale maturity determination by Raman spectroscopy measurement with minimal sample preparation. Int. J. Coal Geol. 2017, 173, 150-157. [CrossRef]

65. Henry, D.G.; Jarvis, I.; Gillmore, G.; Stephenson, M. A rapid method for determining organic matter maturity using laser Raman spectroscopy: Application to Carboniferous organic-rich mudstones and coals. Int. J. Coal Geol. 2019, 203, 87-98. [CrossRef]

66. Khatibi, S.; Ostadhassan, M.; Aghajanpour, A. Raman spectroscopy: An analytical tool for evaluating organic matter. J. Oil Gas Petrochem. Sci. 2018, 1, 28-33. [CrossRef]

67. Khatibi, S.; Ostadhassan, M.; Tuschel, D.; Gentzis, T.; Bubach, B.; Carvajal-Ortiz, H. Raman spectroscopy to study thermal maturity and elastic modulus of kerogen. Int. J. Coal Geol. 2018, 185, 103-118. [CrossRef]

68. Gorbanenko, O.O.; Ligouis, B. Changes in optical properties of liptinite macerals from early mature to post mature stage in Posidonia Shale (Lower Toarcian, NW Germany). Int. J. Coal Geol. 2014, 133, 47-59. [CrossRef]

69. Hackley, P.C.; Araujo, C.V.; Borrego, A.G.; Bouzinos, A.; Cardott, B.J.; Cook, A.J.; Eble, C. Standardization of reflectance measurements in dispersed organic matter: Results of an exercise to improve interlaboratory agreement. Mar. Pet. Geol. 2015, 59, 22-34. [CrossRef]

70. Carvajal-Ortiz, H.; Gentzis, T. Critical considerations when assessing hydrocarbon plays using Rock-Eval pyrolysis and organic petrology data: Data quality revisited. Int. J. Coal Geol. 2015, 152, 113-122. [CrossRef]

71. Tuinstra, F.; Lo Koenig, J. Raman spectrum of graphite. J. Chem. Phys. 1970, 53, 1126-1130. [CrossRef]

72. Yui, T.-F.; Huang, E.; Xu, J. Raman spectrum of carbonaceous material: A possible metamorphic grade indicator for low-grade metamorphic rocks. J. Metamorph. Geol. 1996, 14, 115-124. [CrossRef]

73. Marshall, C.P.; Edwards, H.G.M.; Jehlicka, J. Understanding the application of Raman spectroscopy to the detection of traces of life. Astrobiology 2010, 10, 229-243. [CrossRef]

74. Ferralis, N.; Matys, E.D.; Knoll, A.H.; Hallmann, C.; Summons, R.E. Rapid, direct and non-destructive assessment of fossil organic matter via microRaman spectroscopy. Carbon 2016, 180, 440-449. [CrossRef]

75. Baludikay, B.K.; François, C.; Sforna, M.C.; Beghin, J.; Cornet, Y.; Storme, J.-Y.; Fagel, N.; Fontaine, F.; Littke, R.; Baudet, D.; et al. Raman microspectroscopy, bitumen reflectance and illite crystallinity scale: Comparison of different geothermometry methods on fossiliferous Proterozoic sedimentary basins (DR Congo, Mauritania and Australia). Int. J. Coal Geol. 2018, 191, 80-94. [CrossRef]

76. Ostadhassan, M.; Liu, K.; Li, C.; Khatibi, S. Fine Scale Characterization of Shale Reservoirs: Methods and Challenges; Springer: Berlin/Heidelberg, Germany, 2018.

77. Cesare, B.; Maineri, C. Fluid-present anatexis of metapelites at El Joyazo (SE Spain): Constraints from Raman spectroscopy of graphite. Contrib. Miner. Petrol. 1999, 135, 41-52. [CrossRef]

78. Ferrari, A.C.; Robertson, J. Resonant Raman spectroscopy of disordered, amorphous, and diamondlike carbon. Phys. Rev. B 2001, 64, 075414. [CrossRef]

79. Li, Z.; Fredericks, P.M.; Ward, C.R.; Rintoul, L. Chemical functionalities of high and low sulfur Australian coals: A case study using micro attenuated total reflectance-Fourier transform infrared (ATR-FTIR) spectrometry. Org. Geochem. 2010, 41, 554-558. [CrossRef]

80. Aileen, M.-R.; Grotheer, H.; Bourdet, J.; Suvorova, A.; Grice, K.; McCuaig, T.C.; Greenwood, P.F. Evidence and origin of different types of sedimentary organic matter from a Paleoproterozoic orogenic Au deposit. Precambrian Res. 2017, 299, 319-338. 
81. Spötl, C.; Houseknecht, D.W.; Jaques, R.C. Kerogen maturation and incipient graphitization of hydrocarbon source rocks in the Arkoma Basin, Oklahoma and Arkansas: A combined petrographic and Raman spectrometric study. Org. Geochem. 1998, 28, 535-542. [CrossRef]

82. Trudinger, P.A.; Walter, M.R.; Ralph, B.J. (Eds.) Biogeochemistry of Ancient and Modern Environments: Proceedings of the Fourth International Symposium on Environmental Biogeochemistry (ISEB) and, Conference on Biogeochemistry in Relation to the Mining Industry and Environmental Pollution (Leaching Conference), Held in Canberra, Australia, 26 August-4 September 1979; Springer Science \& Business Media: Berlin/Heidelberg, Germany, 2013.

83. Van Krevelen, D.W. Graphical-statistical method for the study of structure and reaction processes of coal. Fuel 1950, 29, 269-284.

84. Scott, A.C.; Glasspool, I.J. Observations and experiments on the origin and formation of inertinite group macerals. Int. J. Coal Geol. 2007, 70, 53-66. [CrossRef]

85. Hower, J.C.; O’Keefe, J.M.K.; Watt, M.A.; Pratt, T.J.; Eble, C.F.; Stucker, J.D.; Richardson, A.R.; Kostova, I.J. Notes on the origin of inertinite macerals in coals: Observations on the importance of fungi in the origin of macrinite. Int. J. Coal Geol. 2009, 80, 135-143. [CrossRef]

86. Bustin, R.M.; Link, C.; Goodarzi, F. Optical properties and chemistry of graptolite periderm following laboratory simulated maturation. Org. Geochem. 1989, 14, 355-364. [CrossRef]

87. Borrego, A.G.; Hagemann, H.W.; Prado, J.G.; Guillén, M.D.; Blanco, C.G. Comparative petrographic and geochemical study of the Puertollano oil shale kerogens. Org. Geochem. 1996, 24, 309-321. [CrossRef]

88. Crelling, J.C.; Dutcher, R.R. Principles and Applications of Coal Petrology: Short Course Notes; No. 8; Society of Economic Paleontologists \& Mineralogists: New York, NY, USA, 1980.

89. Cardott, B.J. Thermal maturity of Woodford Shale gas and oil plays, Oklahoma, USA. Int. J. Coal Geol. 2012, 103, 109-119. [CrossRef]

90. Wei, L.; Wang, Y.; Mastalerz, M. Comparative optical properties of vitrinite and other macerals from Upper Devonian-Lower Mississippian New Albany Shale: Implications for thermal maturity. Int. J. Coal Geol. 2016, 168, 222-236. [CrossRef]

91. Mählmann, R.F.; Le Bayon, R. Vitrinite and vitrinite like solid bitumen reflectance in thermal maturity studies: Correlations from diagenesis to incipient metamorphism in different geodynamic settings. Int. J. Coal Geol. 2016, 157, 52-73. [CrossRef]

92. Hackley, P.C.; Lewan, M. Understanding and distinguishing reflectance measurements of solid bitumen and vitrinite using hydrous pyrolysis: Implications to petroleum assessment. AAPG Bull. 2018, 102, 1119-1140. [CrossRef]

93. Liu, D.; Xiao, X.; Tian, H.; Min, Y.; Zhou, Q.; Cheng, P.; Shen, J. Sample maturation calculated using Raman spectroscopic parameters for solid organics: Methodology and geological applications. Chin. Sci. Bull. 2013, 58, 1285-1298. [CrossRef]

94. Hampartsoumian, E.; Nimmo, W.; Rosenberg, P.; Thomsen, E.; Williams, A. Evaluation of the chemical properties of coals and their maceral group constituents in relation to combustion reactivity using multi-variate analyses. Fuel 1998, 77, 735-748. [CrossRef]

95. Dembicki, H. Practical Petroleum Geochemistry for Exploration and Production; Elsevier: Amsterdam, The Netherlands, 2016.

96. Altun, N.E.; Hicyilmaz, C.; Hwang, J.-Y.; Bagci, A.S.; Kok, M.V. Oil shales in the world and Turkey; reserves, current situation and future prospects: A review. Oil Shale 2006, 23, 211-228.

97. Kelemen, S.R.; Afeworki, M.; Gorbaty, M.L.; Sansone, M.; Kwiatek, P.J.; Walters, C.C.; Freund, H.; Siskin, M.; Bence, A.E.; Curry, D.J.; et al. Direct characterization of kerogen by X-ray and solid-state 13 C nuclear magnetic resonance methods. Energy Fuels 2007, 21, 1548-1561. [CrossRef]

98. Orr, W.L. Kerogen/asphaltene/sulfur relationships in sulfur-rich Monterey oils. Org. Geochem. 1986, 10, 499-516. [CrossRef]

99. Gentzis, T.; Goodarzi, F. A review of the use of bitumen reflectance in hydrocarbon exploration with examples from Melville Island, Arctic Canada. In Applications of Thermal Maturity Studies to Energy Exploration; Rocky Mountain Section (SEPM): Denver, CO, USA, 1990; pp. 23-36.

100. Khorasani, G.K.; Michelsen, J.K. The thermal evolution of solid bitumens, bitumen reflectance, and kinetic modeling of reflectance: Application in petroleum and ore prospecting. Energy Sources 1993, 15, 181-204. [CrossRef] 
101. Schoenherr, J.; Littke, R.; Urai, J.L.; Kukla, P.A.; Rawahi, Z. Polyphase thermal evolution in the Infra-Cambrian Ara Group (South Oman Salt Basin) as deduced by maturity of solid reservoir bitumen. Org. Geochem. 2007, 38, 1293-1318. [CrossRef]

102. Kelemen, S.R.; Walters, C.C.; Kwiatek, P.J.; Freund, H.; Afeworki, M.; Sansone, M.; Lamberti, W.A.; Pottorf, R.J.; Machel, H.G.; Peters, K.E.; et al. Characterization of solid bitumens originating from thermal chemical alteration and thermochemical sulfate reduction. Geochim. Cosmochim. Acta 2010, 74, 5305-5332. [CrossRef]

(C) 2020 by the authors. Licensee MDPI, Basel, Switzerland. This article is an open access article distributed under the terms and conditions of the Creative Commons Attribution (CC BY) license (http://creativecommons.org/licenses/by/4.0/). 